\title{
PERAN PENDIDIKAN KARAKTER DALAM PENGUATAN NILAI-NILAI KEBANGSAAN ${ }^{1}$
}

\author{
Sjamsi Pasandaran \\ Dosen Jurusan Pendidikan Pancasila dan Kewarganegaraan FIS UNIMA
}

\begin{abstract}
Abstrak
Setiap negara dan pemerintahan mempuyai kepentingan nilai yang sangat mendasar yaitu memperkuat nilai-nilai kebangsaan. Nilai-nilai kebangsaan itu akan menjadi landasan bagi bangunan kehidupan bermasyarakat, berbangsa, dan bernegara. Apabila niai-nilai kebangsaan itu melemah, akan sangat berpengaruh terhadap kehidupan dan bahkan terhadap kelangsungan hidup suatu bangsa ataupun negara. Menjelang pertengahan 2012, Indonesia sempat menjadi gempar ketika Lembaga The Fund for Peace (FFP) melaporkan bahwa Indonesia terancam menjadi negara "gagal" dan menempati posisi ke 63 dari 178 negara (Kompas.com, 21 Juni 2012). Dua tahun sebelumnya, Lembaga Transparency International Indonesia pada 2010 menurunkan laporan mengenai ancaman-ancaman menuju kehancuran yang akan dihadapi oleh bangsa Indonesia. Tingkat ancaman-ancaman tersebut persentasenya secara berturut-turut adalah sebagai berikut: budaya korupsi merupakan ancaman yang sangat serius dan dipersepsi oleh $38.5 \%$ responden, kemudian diikuti oleh krisis ekonomi (15.1\%), pengangguran (10.3\%), terorisme dan keamanan $(9.7 \%)$, konflik antara kelompok $(9.3 \%)$, dan layanan birokrasi yang buruk $(5.6 \%)$.
\end{abstract}

Kata Kunci: Pendidikan Karakter, Nilai-nilai Kebangsaan

\footnotetext{
${ }^{1}$ Tulisan ini merupakan pengembangan dari dua tulisan penulis yaitu Penguatan Wawasan Kebangsaan Melalui Pendidikan Karakter dan Membangun Karakter Bangsa Melalui Pendidikan Karakter yang diterbitkan di Majalah Dewan Pertimbangan Presiden, Edisi Desember Tahun 2011 dan Tahun 2012.
} 


\section{Pendahuluan}

Kecenderungan melemahnya nilai-nilai kebangsaan teramati pula dalam sikap dan perilaku yang masih menjadi keprihatinan bersama hingga saat. Keprihatinan itu muncul ketika secara empirik teramati sikap dan perilaku kohesi sosial yang semakin melemah yang ditandai dengan semakin maraknya tawuran mulai dari elit terpelajar (mahasiswa-siswa) sampai ke tawuran antar warga di kota ataupun di desa-desa bahkan pada tataran atas nampak pada perseteruan yang berkelanjutan para elit politik yang tidak mendidik. Krisis keteladanan dimulai dari kehidupan keluarga, masyarakat, termasuk para pemimpin formal di berbagai institusi; baik pemerintahan, sosial, politik, maupun pendidikan. Perilaku koruptif yang sudah masuk kategori extra ordinary crime. Untuk perilaku koruptif ini, Transparency International menurunkan laporan 2011 yang menempatkan indeks persepsi korupsi (IPK) Indonesia pada peringkat 100 dengan skor 3.00 dari 142 negara. Bahkan di antara negaranegara Asean Indonesia berada di bawah Singapore pada posisi ke-5 dengan skor 9.2, Brunei Darusalam posisi 44 dengan skor 5.2, Malaysia posisi 60 dengan skor 4.3, dan Thailand pada posisi 80 dengan skor 3.4 .

Nilai-nilai kebangsaan menjadi semakin penting bagi bangsa Indonesia dalam membangun dan untuk memperkuat kehidupan masyarakat yang sangat pluralistik. Urgensi itu di satu sisi terkait dengan realitas kemajemukan masyarakat, dalam realtitas itu kita belum mampu membangun kehidupan bersama yang menghargai kemajemukan yang ada. Dalam kehidupan dan melalui laporan media masa baik cetak maupun elektronik masih teramati kecenderungan semakin meluasnya konflik horisontal, kesenjangan ekonomi masyarakat dan antar daerah yang masih dirasakan, pengabaian atas hak-hak asasi manusia, lemahnya jaminan terhadap kebebasan beragama kelompokkelompok minoritas, rendahnya kesadaran dan penghormatan terhadap simbol-simbol negara, rasa keadilan masyarakat yang terusik, rasa ketenteraman masyarakat terusik dengan perilaku anarkistik ketika hendak berdemonstrasi. Di pihak lain, nilai-nilai kebangsaan ini mempunyai peran yang sangat besar karena terkait dengan identitas diri sebagai masyarakat, bangsa dan negara atau sebagai identitas kebangsaan.
Identitas kebangsaan yang berisi nilai-nilai kebangsaan itu harus mendorong tumbuhnya rasa kebanggaan diri sebagai suatu bangsa. Identitas kebangsaan akan mendorong sikap dan perilaku yang menjunjung tinggi nilai-nilai kebangsaan itu.

Dalam tatanan kehidupan masyarakat global sekarang ini, nilai-nilai kebangsaan hendaknya menjadi landasan dan memberi arah terhadap pembangunan bangsa dan negara sehingga kita tidak tercabut dari akar budaya, tetapi tumbuh kuat di atas nilai-nilai kebangsaan. Hal ini penting karena di era global persaingan akan semakin meningkat dan akan terjadi pergeseran-pergeseran nilai. Terdapat tiga arus kuat globalisasi yang harus disikapi dan dihadapi bersama yang dapat mempengaruhi nilai-nilai kebangsaan yaitu arus kuat teknologi informasi dan komunikasi, perkembangan ekonomi regional dan dunia, dan perkembangan di bidang politik. Sebagai bagian dari komunitas global, Indonesia masuk dan menjadi bagian dari berbagai komunitas seperti ASEAN Community 2015 dalam membangun kehidupan bersama baik dalam bidang ekonomi, politik, maupun social budaya. Dalam konteks ekonomi, Indonesia menjadi bagian dari ASEAN Free Trade Area (AFTA), dan bersama-sama menyepakati General Agreement on Trade in Services (GATS). Nilainilai kebangsaan ini pun mejadi sangat penting ketika Indonesia menjadi salah satu anggota G20. Perdebatan mengenai urgen tidaknya Indonesia bahkan berkembangnya pemikiran agar Indonesia keluar dari G-20 karena tidak menguntungkan memberi gambaran tentang adanya persoalan nilai-nilai kebangsaan yang masih terus harus diperjuangkan.

\section{Permasalahan Penguatan Nilai-nilai Kebangsaan}

Berbicara tentang nilai-nilai kebangsaan, tidak hanya terbatas pada wacana, slogan, dan himbauan. Nilai-nilai kebangsaan harus nyata dalam sikap dan perilaku dan menjadi karakter. Karakter akan menjadi ciri identitas kebangsaan. Oleh sebab itu persoalan pokok ke depan adalah bagaimana membangun dan memperkuat pembentukan karakter bangsa melalui pendidikan karakter. Sekalipun demikian terdapat beberapa masalah dalam upaya penguatan nilai-nilai kebangsaan melalui pendidikan karakter. 
Masalah-masalah tersebut dapat dijelaskan sebagai berikut.

a. Pendidikan karakter dipahami secara terbatas yaitu sebagai bagian dari program pendidikan formal di sekolah dalam arti civic education. Pendidikan karakter belum menjadi bagian dari citizenship education dimana semua lembaga atau institusi mempunyai peran dan tanggunjawab dalam memperkuat nilai-nilai kebangsaan sehingga menjadi karakter dan identitas bangsa. Institusi-institusi pemerintahan, politik, agama, social, budaya, pendidikan dan bahkan ekonomi memiliki tanggungjawab bersama dalam membangun karakter bangsa. Belum terbangun sinergitas yang kuat antar institusi bahkan kecenderungan yang ada menunjukkan lemahnya pendidikan karakter di banyak institusi. Praktik-praktik seperti korupsi, kolusi, nepotisme, menguatnya kepentingan kelompok, primordialisme baik karena suku, agama, maupun aliran politik mengekspresikan lemahnya upaya-upaya pembentukan karakter yang baik warganegara dan warga masyarakat. Anak-anak akan mengalami disonansi kognitif atau cognitive dissonance ketika di sekolah mereka diajari nilai-nilai kebangsaan yang baik tetapi di dalam kehidupan sehari-hari mereka disuguhkan dengan perselisihan, pertengkaran, dan perseteruan antar elit politik, praktik manipulatif para pemimpin, dan bahkan tindakan-tindakan anarkistik yang terjadi di masyarakat.

b. Kelemahan dalam proses internalisasi dan institusionalisasi nilai-nilai kebangsaan dari berbagai instrument nilai. Hampir semua pemimpin dan lembaga memiliki visi sebagai cita-cita yang menjadi standar nilai. Bahkan visi ini menjadi bagian penting dalam proses seseorang untuk menjadi pemimpin, dan menjadi keharusan bagi setiap lembaga untuk memiliki visi. Visi ini kemudian dijabarkan dalam berbagai instrument baik yang sifatnya programatik maupun yuridis. Namun demikian visi, misi, program dan berbagai instrument yuridis belum menjadi bagian dari sikap dan perilaku kita semua. Nilai-nilai itu belum menjadi karakter dan diperlukan suatu proses karakterisasi. Dua kelemahan yang teramati dalam proses karakterisasi nilai-nilai kebangsaan adalah lemahnya proses internalisasi dan institusionalisasi nilai-nilai kebangsaan yang implicit dirumuskan dalam berbagai isntrumen. Nilai-nilai kebangsaan harus dihayati, dan sekaligus menjadi ciri karakter baik individu maupun lembaga. Laporan Komisi Pemberantasan Korupsi (KPK) mengenai adanya lembaga-lembaga pemerintahan (kementerian atau non kemeneterian) yang dinilai tidak bersih menunjukkan bahwa secara kelembagaan proses internalisasi dan institusionalisasi nilai-nilai kenagsaan belum optimal.

c. Kelemahan dalam praksis pendidikan karakter di sekolah-sekolah. Sekolah memang mempunyai tanggungjawab yang sangat besar dalam membangun, memperkuat nilai-nilai kebangsaan melalui pendidikan karakter. Kelemahan yang sangat mendasar dalam praksis pendidikan karakter di sekolahsekolah praksis yang fragmentaristik dalam penyelenggaraan pendidikan karakter, dilaksanakan terpisah dan belum merupakan program utuh dalam keseluruhan proses pembelajaran. Pendidikan karakter seolaholah hanya menjadi tanggungjawab guru mata pelajaran Pendidikan Agama dan atau Pendidikan Kewarganegaraan. Sekolah belum menjadi lingkungan belajar dalam pembentukan nilai-nilai kebangsaan, dan praktik pembelajaran sangat kuat pada pengembangan spek kognitif yang sehingga yang terjadi adalah proses transfer of knowledge yaitu pembelajaran pengetahuan mengenai nilai dan bukan pada proses yang mendorong terjadinya pembentukan sikap dan perilaku moral yang baik.

\section{Pembahasan.}

\section{Nilai-nilai Kebangsaan}

Berbicara tentang nilai-nilai kebangsaan memerlukan pemahaman bersama mengenai nilai. Nilai selalu akan menunjuk pada kualitas atau standar yang menjadi acuan untuk menyatakam sesuatu bernilai baik sikap, perilaku, ide ataupun gagasan, benda, peristiwa, ataupun produk. Nilai-nilai tersebut memiliki fungsi untuk memberikan arah baik bagi individu, masyarakat, bangsa dan negara dan ataupun institusi. Shalom Schwartz mendfinisikan nilai dan fungsi nilai sebagai berikut: 
...values as conceptions of the desirable that guide the way social actors (e.g. organisational leaders, policy-makers, individual persons) select actions, evaluate people and events, and explain their actions and evaluations. In this view, values are transsituational criteria or goals (e.g. security, hedonism), ordered by importance as guiding principles in life $^{2}$

Nilai-nilai kebangsaan merupakan standar etik yang diakui, diterima, dan diyakini sebagai suatu yang baik dan benar oleh suatu masyarakat bangsa, dan negara. Nilai-nilai itu tumbuh, berkembang dan menjadi a common spiritual and psychological sentiment ${ }^{3}$ sebagai ciri kebangsaan. Sebagai ciri kebangsaan, maka nilai-nilai kebangsaan akan mencerminkan jati diri, identitas bangsa atau nation identity. Nilai-nilai kebangsaan ini akan menjadi kekuatan motivasional bagi perilaku baik individu maupun sosial. Nilai-nilai kebangsaan yang kuat di dalam diri seorang atlit misalnya akan menjadi kekuatan motivasional untuk berprestasi, menjadi kekuatan motivasional untuk berkorban bagi bangsa dan negara. Nilai-nilai kebangsaan dengan demikian akan menjadi kekuatan suatu bangsa untuk memperkuat ketahanan, pembelaan dan pembangunan bangsa dan negara.

Nilai-nilai kebangsaan dilandasi oleh sistem nilai yang dipercayai, yang telah teruji kebenarannya melalui perjalanan sejarah suatu bangsa, negara, dan masyarakat. Nilai-nilai itu apabila terinternalisasi melalui proses karakterisasi, akan menjadi karakter seseorang, masyarakat, bangsa dan negara. Sebagai bangsa secara normatif, sosiologis, politis, dan kultural kita memiliki nilai-nilai kebangsaan yang tercermin di dalam nilai-nilai Pancasila, UUD 45, NKRI, dan Binneka Tunggal Ika. Nilai-nilai kebangsaan itu tersebut berisi nilai-nilai dasar yang diharapkan akan menjadi ciri karakter kehidupan berbangsa, bernegara, dan

\footnotetext{
${ }^{2}$ Shalom Schwartz, 1999, A Theory of Cultural Values and Some Implications for Work. P. 24 http://wwwkrcmar.in.tum.de/lehre\%5Clv materialien.nsf $/ \mathbf{i}$ ntern01/ (diakses 20 Nopember 2014)

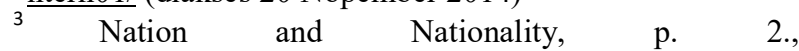
http://www.newagepublishers.com/ (diakses, 20 Nopember 2014).
}

bermasyarakat. Nilai-nilai itu secara sosiologis dan kultural tumbuh dan berkembangan melalui sejarah perjalanan bangsa Indonesia, dan terkristalisasi sebagai norma dalam bangunan kehidupan NKRI. Menjadi imperatif bahwa nilainilai kebangsaan yang hendak dibangun, hendaknya mencirikan cara pandang yang dilandasi, dijiwai, dan disemangati oleh nilai-nilai dasar dan kebangsaan itu. Penguatan nilai-niai kebangsaan akan sangat dipengaruhi oleh preferensi nilai yang dimiliki baik individu maupun institusi. Preferensi nilai pada gilirannya akan menjadi kekuatan motivasional bagi perilaku individu, sosial, ataupun institusi.

Pancasila merupakan kristalisasi nilai dari sistem nilai kemasyarakatan Indonesia yang sangat majemuk, Nilai-nilai Pancasila digali dari sistem nilai yang telah hidup di sepajang sejarah bangsa Indonesia. Di dalam Pancasila terkandung nilai-nilai dasar universal yang tumbuh dari sistem nilai kemasyarakatan dari berbagai lingkungan masyarakat adat, tradisi, agama, maupun sistem kepercayaan. Akar budaya nilainilai Pancasila tersebut, memperkokoh kedudukan Pancasila sebagai pandangan hidup, filosofi, ideologi, dan dasar negara dalam bangunan ketatanegaraan Indonesia. Dengan demikian Pancasila memuat nilai-nilai dasar kebangsaan Indonesia yang mendasari keseluruhan bangunan kemasyarakatan, kebangsaan, dan kenegaraan.

Undang-undang Dasar 1945 memuat nilainilai kebangsaan yang menjadi landasan konstitusional pembangunan hukum ketenegaraan. Nilai-nilai kebangsaan yang terkandung di dalam UUD 1945 adalah (1) jaminan kebebasan beragama terhadap setiap warganegara, (2) kedaulatan berada di tangan rakyat, (3) supremasi hukum dan kesamaan kedudukan warganegara di dalam hukum dan pemerintahan, dan hak atas kehidupan yang layak,serta dalam pembelaan negara, (4) jaminan perlingungan hak asasi manusia, (5) kedaulatan rakyat, (6) Negara Kesatuan Republik Indonesia, (7) nilai-nilai demokrasi, (8) perekonomian bagi kesejahteraan seluruh rakyat Indonesia, (9) Menjunjung tinggi bahasa Indonesia sebagai bahasa negara, bendera merah putih sebagai bendera negara, Garuda Pancasila dan Bhineka Tunggal Ika sebagai lambang negara, dan Indonesia Raya sebagai lagu kebangsaan, dan 
(10) pendidikan dan kebudayaan dalam mencerdaskan kehidupan bangsa. Kesepuluh nilai-nilai kebangsaan ini merupakan core values dalam menjamin konstitusionalitas pengelolaan dan penyelenggaraan kehidupan kemasyarakatan, ketatanegaraan dan kehidupan kebangsaan.

Negara Kesatuan Republik Indonesia (NKRI) merupakan nilai kebangsaan yang menempatkan dan menjadikan Indonesia dalam satu wadah negara yang tidak dipisahkan oleh kondisi geograifs yang terdri dari puluhan ribu pulau. NKRI menjamin keutuhan wilayah negara Indonesia sebagai suatu bangsa, menjembatani dan menyatukan seluruh wilayah kepulauan Indonesia. NKRI juga memuat nilai-nilai kebangsaan yang menjamin pembangunan yang menjangkau keseluruhan wilayah NKRI sampai ke daerah-daerah tertinggal, terluar dan terkebelakang baik karena faktor geografis maupun karena factor kemiskinan. Dalam perspektif ini nilai-nilai kebangsaan justeru diukur pada jaminan keutuhan pembangunan yang menjangkau dan yang dapat dijangkau dan dinikmati oleh seluruh rakyat Indonesia. Keterbelakangan yang terjadi akan merupakan pengingkaran terhadap nilai-nilai kebangsaan.

Bhineka Tunggal Ika merupakan semboyang yang memuat nilai-nilai kebangsaan dalam menjamin keharmonisan hidup bermasyarakat, berbangsa, dan bernegara dalam masyarakat Indonesia yang sangat majemuk. Nilai-nilai kebangsaan yang terkandung di dalam semboyang Bhineka Tunggal Ika didorong pula oleh kesadaran kemanusiaan yaitu manusia sebagai makhluk social yang hidup dalam suatu komunitas sebagai masyarakat, bangsa, dan negara. Keharmonisian itu terjelma dalam praktik dan tradisi gotong royong dalam berbagai bentuk di masyarakat adat, saling menolong, saling menghormati tanpa membedakan suku, agama, dan bahasa. Kerukunan hidup antar umat beragama atau sikap toleransi menjadi ciri kehidupan masyarakat Indonesia, sekalipun saat ini terusik oleh kecenderungan gerakan fundamentalisme dan radikalisme.

\section{Pendidikan Karakter sebagai Pilar Penguatan Nilai-nilai Kebangsaan \\ a. Hakikat Pendidikan Karakter}

Pendidikan karakter menjadi media yang sangat strategis dalam rangka internalisasi dan karakterisasi nilai-nilai kebangsaan. Pendidikan karakter dalam konteks ini dipahami sebagai suatu proses internalisasi dan karakterisasi nilainilai dasar kebangsaan, sehingga nilai-nilai itu menjadi ciri perilaku dalam kehidupan bermasyarakat berbangsa, dan bernegara. Para ahli seperti Howard dan Berkowitz merumuskan fungsi dan peran pendidikan karakter sebagai berikut:

Character education is an attempt to prepare individuals to make ethical judgments and to act on them, that is, to do what one thinks ought to be done. ... Character education, a vital tool for preparing our young people in our schools, has had to confront political issues and challenges of its own $^{4}$

Dilihat dari definisi yang dikemukakan oleh Howard dan Berkowitz tersebut tampak bahwa pendidikan karakter mempunyai tugas untuk mempersiapkan individu untuk dapat membuat pertimbangan etik dan melakukannya itu melalui tindakan. Oleh sebab itu pendidikan karakter selalu terkait dengan upaya mempersiapkan seseorang menjadi warganegara yang baik, melakukan apa secara etis harus dilakukannya. Tidak hanya memiliki pertimbangan etik atau moral yang baik, tetapi juga melakukannya itu sebagai suatu keharusan. Pendidikan karakter dengan demikian menjadi sangat penting untuk mempersiapkan seseorang menjadi warganegara yang baik.

Karakter yang baik, memiliki tiga komponen utama yaitu knowing the good, desire the good, and doing the good ${ }^{5}$. Seseorang memiliki karakter yang baik pertama-tama mengetahui apa yang baik (knowing the good). Mengetahui apa yang baik belum cukup, tetapi harus memiliki kesukaan, kecintaan dan kehendak terhadap apa yang baik (desire the good atau loving the good). Komponen ketiga yang sangatpenting ialah melakukan apa yang baik atau doing the good. Ketiga komponen tersebut secara utuh melibatkan aspk-aspek

\footnotetext{
${ }^{4}$ Robert Howard, Marvin Berkowitz, and Esther Schaeffer, 2004, Politcs of Character Education, Educational Policy, Vol. 18 No. 1, January and March 2004, p. 189. http://www.fresnostate.edu/

5 Kevin Ryan and Karen E. Bohlin, 1999, Building Character In Schools, Jossey Bass, San Fransisco, p. 5
} 
kognitif, afektif, dan psikomotorik. Oleh sebab itu pendidikan karakter harus pula mencakup ketiga komponen karakter itu. Artinya pendidikan karakter harus membelajarkan kepada anak mengenai apa yang baik sehingga mengetahui apa yang baik atau knowing the good. Membelajarkan apa yang baik tidaklah terlalu sulit. Kesulitan akan muncul ketika hendak membentuk sikap dan konasi anak untuk menyukai dan mencintai yang baik. Pembelajaran pendidikan karakter harus mampu membentuk sikap yang baik di dalam diri anak. Komponen yang sesungguhnya harus menjadi ultimate goal pendidikan karakter adalah perilaku atau tindak moral yang melakukan apa yang baik atau doing the good. Keutuhan ketiga komponen ini sudah harus terinternalisasi dan menjadi suatu kebiasaan. Kevin Ryan dan Karen Bohlin mengemukakannya sebagai habits of the head, the heart and the hand ${ }^{6}$. Kebiasaankebiasaan itu terintegrasi sebagai ciri kepribadian seseorang yang memiliki karakter yang baik.

Dalam perspektif penguataan nilai-nilai kebangsaan, pendidikan karakter memiliki fungsi yaitu membelajarkan dan mempersiapkan warganegara untuk memiliki pengetahuan nilainilai dasar kebangsaan baik yang terkandung di dalam Pancasila, UUD 1945, NKRI, maupun Bhineka Tunggal Ika. Dalam konteks ini pendidikan karakter harus dilihat sebagai suatu proses pewarisan nilai-nilai kebangsaan. Pewarisan nilai-nilai kebangsaan itu harus diikuti dengan menumbuhkan sikap, keinginan, dan kecintaan terhadap nilai-nilai kebangsaan itu sendiri. Pengetahuan tentang nilai-nilai kebangsaan diperlukan dalam rangka pembentukan sikap kebangsaan seperti kebanggaan berbangsa dan bertanah air Indonesia, demokratis dan memiliki sikap kepedulian terhadap nilai-nilai kebangsaan itu. Pengetahuan dan sikap itu pada gilirannya diharapkan akan menumbuhkan perilaku etik sebagai warganegara negara yang baik. Perilaku etikdalam mengimplementasikan nilai-nilai kebangsaan itu harus menjadi bagian dari ciri kepribadian setiap warganegara, dan sebagai suatu bangsa hal itu akan menjadi identitas bangsa atau nation identity sebagai bangsa Indonesia.

\footnotetext{
${ }^{6}$ Ibid., p. 7
}

Pendidikan karakter memiliki perspektif yang sangat dimulai karena dimulai keluarga, lingkungan sekolah, masyarakat, dan bahkan negara. Oleh sebab itu pendidikan karakter menjadi tanggungjawab bersama. Diperlukan gerakan bersama oleh semua komponen bangsa melalui keterlibatan semua institusi. Keluarga merupakan institusi pertama dan utama dalam meletakkan dan membentuk dasar-dasar kehidupan berkarakter. Pemerintah mempunyai kewajiban dan tanggungjawab untuk menjamin pengembangan dan keterlaksanaan pendidikan karakter secara efektif. Lembaga-lembaga lain seperti lembaga keagamaan, politik, dan sosial kemasyarakatan ikut mempunyai tanggungjawab dalam membangun karakter berwawasan kebangsaan. Institusi peradilan dan penegak hukum pun mempunyai kewajiban dan tanggungjawab merepresentasi tentang nilai-nilai keadilan, kejujuran, dan kebenaran. Akhirnya lembaga pendidikan sebagai lembaga formal menyelenggarakan pendidikan karakter mempunyai tanggungjawab mengembangkan proses pendidikan yang tidak terjebak dalam proses indoktrinasi.

\section{b. Internalisasi dan Institusionalisasi Nilai- Nilai Kebangsaan}

Keteladan dan habituasi merupakan praktik metodologis yang efektif dalam proses karakterisasi nilai-nilai kebangsaan. Guru, orang tua, dan para pemimpin di berbagai institusi harus menjadi contoh dan teladan bagi sesamanya baik dalam hal kejujuran, kedisiplinan, tanggungjawab, dan atau kepedulian terhadap kehidupan dan masalah bersama. Keteladanan dan penerusan nilai-nilai dapat dikemas melalui interaksi edukatif dan kegiatan pembelajaran yang memberi ruang bagi berkembangnya kreativitas, keterbukaan, toleran terhadap keragaman, kejujuran, obyektivitas, kritis konstruktif, dan menjunjung tinggi hak dan kewajiban sebagai warganegara. Habituasi dapat dimulai dari lingkungan keluarga, sekolah, lingkungan kerja dan ruang dimana terjadi interaksi edukatif.

Internalisasi nilai-nilai kebangsaan adalah suatu proses pembelajaran dan habituasi sehingga terjadi penghayatan nilai-nilai kebangsaan. Proses internalisasi ini penting sehingga nilai itu terinternalisasi di dalam hati dan diri seseorang 
yang ditandai oleh penerimaan terhadap nilainilai itu sendiri. Penerimaan ini akan mendorong seseorang untuk merespons dalam bentuk tanggapan dan sikap terhadap nilai. Proses lebih jauh ialah melalu internalisasi yang baik dan kuat, akan menjadi landasan yang kuat bagi individu untuk melakukan penilaian dalam mengambil keputusan etik, dalam menentukan mana yang baik dan benar. Dalam mengambil keputusan etik ini, seseorang akan diperhadapkan kepada pilihan-pilihan nilai, dan internalisasi nilai yang kuat akan memperkuat landasan pengambilan keputusan etik tersebut. Keputusan-keputusan yang diambil dalam situasi dilematik umumnya dilandasi oleh pertimbangan-pertimbangan etik hasil dari penghayatan atas suatu nilai atau atas nilai-nilai tertentu yang menjadi rujukan.

Institusionalisasi adalah suatu proses pelembagaan nilai sehingga menjadi preferensi nilai institusi baik insitutsi pemerintahan, politik, pendidikan, social, agama, budaya, ekonomi dan berbagai institusi yang ada. Institusionalisasi ini penting untuk memperkuat preferensi nilai lembaga, memperkuat pengorganisasian lembaga, dan bahkan meningkatkan kinerja kelembagaan. Nilai-nilai kelembagaan itu akan menjadi landasan etik bagi perilaku semua unsur yang terkait dengan suatu lembaga. Oleh sebab itu institusionalisasi nilai seringkali disebut sebagai institusionalisasi etik. Institusionalisasi nilai ini mempunyai peran dalam proses pengembalian keputusan suatu lembaga, sebab nilai yang terinstitusi itu akan merupakan seperangkat nilai yang secara konsisten akan memberi arah, dorongan, dan kekuatan bagi swetiap individu untuk bersikap dan berperilaku ${ }^{7}$.

\section{c. Penguatan Praksis Pendidikan Karakter}

Disadari bahwa internalisasi dan karakterisasi nilai membutuhkan suatu proses, dan proses itu terjadi melalui pendidikan. Namun demikian, problem yang mendasar ialah pendidikan seperti apa yang diperlukan? Apakah praksis pendidikan selama ini "gagal", sehingga

\footnotetext{
${ }^{7}$ Zaleha Othman and Rashidah Abd Rahman, Recognising Value Based Approach In Corporate Governance: Institutionalization Of Ethics, http://www.wbiconpro.com/
}

berimplikasi pada berbagai fakta perilaku moral dan karakter yang memprihatinkan?

Tampaknya dunia pendidikan Indonesia berada dalam pilihan-pilihan mengenai aspek penting yang harus dibentuk. Problem itu nampak ketika Konvensi Nasional pendidikan Indonesia (Konaspi) VII yang dilaksanakan di Univeritas Yogyakarta (UNY) menetapkan tema "Memantapkan Karakter Bangsa Menuju Generasi 2045". Melalui Konvensi tersebut disadari bahwa paradigma selama ini yang menempatkan kecerdasan terutama Intelligence Quotient (IQ) sebagai indikator penting untuk sukses seseorang belumlah cukup. Aspek penting lainnya ialah Emotional Quotient ((EQ). Para ahli seperti Larry Greider melihat EQ sebagai seperangkat keterampilan yang sangat diperlukan dalam rangka interpersonal relationship, karena kecerdasan emosi mencerminkan kompetensi sosial dan empati seseorang. Kedua aspek tersebut pun belum cukup kuat. Aspek penting lainnya yang justeru kurang mendapatkan perhatian dalam proses pendidikan adalah Spiritual Quotient (SQ) yang justeru berbicara tentang "the meaning of life and ultimate values" (Larry Greider, 2012). Proses pendidikan tidak cukup membekali anak bangsa dengan kecerdasan baik IQ maupun EQ. Setiap anak bangsa perlu dibekali dengan makna hidup dan nilai-nilai utama dalam hidup, sehingga didalam kehidupannya dia menemukan kehidupan yang sungguh sangat bermakna (meaningfull life) baik sebagai pribadi, keluarga, masyarakat, bangsa dan negara.

Proses pendidikan kita memerlukan penguatan aspek SQ seiring dengan kebutuhan penguatan IQ dan EQ. Dalam perspektif ini, kita didorong kembali untuk menempatkan proses pendidikan secara utuh mulai dari keluarga sebagai lembaga utama dan pertama pendidikan, dan seterusnya ke lembaga-lembaga formal pendidikan dan non formal, dan juga berbagai lembaga lainnya baik keagamaan, politik, ekonomi, maupun sosial budaya. Nilai-nilai utama dan kebermaknaan hidup tidak dapat diceramahkan, tetapi internalisasi dan karakterisasinya terbentuk melalui proses interaksi mulai dari kehidupan keluarga, bermasyarakat, berbangsa, dan bernegara.

Penguatan SQ bukanlah hal yang mustahil untuk dilakukan. Sebagai bangsa dan negara kita 
memiliki ultimate values mengenai makna hidup yang terkristalisasi di dalam nilai-nilai Pancasila. Masyarakat kita adalah masyarakat yang religius, memiliki nilai-nilai keagamaan yang sangat penting dan proses religisitas itu diharapkan terbentuk terutama melalui kehidupan keluarga, dan praktik-praktik kehidupan keberagamaan selama ini. Dalam rangka penguatan SQ, Ultimate values hendaknya menjadi moral pendidikan, menjiwai dan menginspirasi keseluruhan praksis pendidikan baik pada tataran konseptual, kebijakan, maupun praktik pendidikan. Internalisasi dan karakterisasi nilainilai utama sangat memerlukan keteladanan. Dalam konteks ini, peran orang tua, guru-guru, dosen, pemimpinan formal dan informal menjadi sangat penting. Proses habituasi nilai-nilai utama di dalam diri, masyarakat ataupun lembaga perlu terus dikembangkan dalam keseluruhan aktivitas dan interaksi baik pribadi, masyarakat maupun berbagai lembaga. Lembaga-lembaga pendidikan baik formal maupun non formal tentunya sudah harus berperan aktif dan efektif dalam menanamkan dan mengembangkan kecerdasan spiritual, seiring dengan pengembangan kecerdasan emosi dan intelektual.

\section{Simpulan}

1. Pendidikan karakter dalam rangka penguatan nilai-nilai kebangsaan mempunyai peranan yang sangat penting. Melalui pendidikan karakter yang efektif akan terjadi proses internalisasi dan institusionalisasi nilai-nilai kebangsaan, sehingga nilai-nilai itu menjadi preferensi nilai baik individu maupun institusi yang menjadi kekuatan motivasional dan yang memberi arah bagi pembangunan kehidupan kemasyarakatan, kebangsaan dan kenegaraan.

2. Terdapat nilai-nilai kebangsaan yang harus terus diperkuat melalui pendidikan karakter, yaitu nilai-nilai dasar filosofis dan ideologis Pancasila, nilai-nilai dasar konstitusional yang termaktub di dalam UUD 1945, nilainilai dasar politik kebangsaan sebagai nilainilai yang terkandung dalam Negara Kesatuan Republik Indonesia, dan nilai-nilai dasar sebagai bangunan kehidupan masyarakat multicultural Indonesia melalui pengakuan terhadap Bhinena Tunggal Ika dalam membangun keharmonisan dalam keragaman (hamony in diversity).

3. Diperlukan sinergitas dalam praksis pendidikan karakter oleh semua komponen baik lembaga pendidikan formal, maupun lembaga-lembaga pemerintahan, politik, ekonomi, social, dan budaya. Berbagai institusi tersebut mempunyai peranan penting sebagai media pendidikan karakter yang dapat memperkuat nilai-nilai kebangsaan. Grand design penguatan sinergitas praksis pendidikan karakter hendaknya mencakup landasan etik, tujuan dan arah pengembangan, jalur dan keterkaitan antar lembaga, muatan atau domain pendidikan yang mencakup aspek-aspek intelektif, sikap, dan perilaku etik.

\section{DAFTAR PUSTAKA}

Anonymous, Nation and Nationality, http://www.newagepublishers.com// (diakses, 20 Nopember 2014)

Kevin Ryan and Karen E. Bohlin, 1999, Building Character In Schools, Jossey Bass, San Fransisco

Robert Howard, Marvin Berkowitz, and Esther Schaeffer,2004, Politcs of Character Education, Educational Policy, Vol. 18 No. 1, January and March 2004, http://www.fresnostate.edu/

Shalom Schwartz, 1999, A Theory of Cultural Values and Some Implications for Work. P. 24

http://wwwkrcmar.in.tum.de/lehre\%5Clv ma terialien.nsf/intern01/ (diakses 20 Nopember 2014

Thomas Lickona, 1992, Educating For Character, How Our Schools Can Teach Respect and Responsibility, Bantam Books, New York.

Zaleha Othman and Rashidah Abd Rahman, Recognising Value Based Approach In Corporate Governance: Institutionalization Of Ethics, http://www.wbiconpro.com/ 